\title{
KESEJAHTERAAN DAN KUALITAS GURU SEBAGAI UJUNG TOMBAK PENDIDIKAN NASIONAL ERA DIGITAL
}

\author{
Firman Mansir ${ }^{1}$ \\ ${ }^{1}$ Universitas Muhammadiyah Yogyakarta \\ firmanmansir@umy.ac.id
}

Received: Nov 2, 2020

Revised: Nov 5, 2020 Accepted: Nov 10, 2020

\begin{abstract}
ABSTRAK
Penelitian ini menjelaskan bahwa persoalan kesejahteraan dan kualitas guru merupakan dimensi yang pertama dan utama dalam mewujudkan pendidikan nasional yang paripurna. Pendidikan di Indonesia saat ini sedang menghadapi masalah yang begitu kompleks, salah satunya adalah rendahnya kualitas tenaga kependidikan atau guru sebagai masalah pokoknya. Selain itu, masih kurangnya kesejahteraan bagi guru juga menjadi masalah pendidikan pada saat ini. Guru merupakan ujung tombak dari pendidikan, dan pendidikan adalah kunci dari pembangunan nasional suatu negara. Karena peran guru yang sangat krusial ini maka penting untuk memberi penghargaan kepada guru atau pendidik. Fakta yang terjadi di Indonesia adalah cerminan kesejahteraan guru masih dianggap kurang, khususnya guru yang berpredikat sebagai honorer. Oleh karena itu, kesejahteraan bagi semua guru perlu menjadi titik perhatian pemerintah dalam rangka mewujudkan pendidikan sejahtera untuk semua guru.
\end{abstract}

Kata Kunci: Kesejahteraan, Kualitas Guru, Pendidikan Nasional

\begin{abstract}
This research describes that the issues of teacher's quality and welfare are the key and important in realize complete national education. Education in Indonesia is currently facing complex problems such as the low quality of teaching staff or teachers as the main problem. Besides, the lack of welfare for teachers is also a problem in education nowadays. Teachers are the spearhead of education, and education is the key to a country's national development. Because of the crucial role of the teacher, it is important to reward the teacher or educator. The fact that occurs in Indonesia is that the teacher's welfare is still considered to be lacking, especially honorary teachers. Therefore, the welfare for all teacher should be the consideration of government in order to make creating prosperous education for all teachers.
\end{abstract}

Keywords: Welfare, Teachers' Quality, National Education. 


\section{PENDAHULUAN}

Salah satu bentuk dari penghargaan kepada guru ialah gaji, gaji guru di Indonesia tergolong masih rendah, apalagi bagi mayoritas guru swasta dan honorer. Jika dibandingkan dengan negara Jepang yang gaji gurunya rata-rata Rp 38 juta/bulan, dan guru yang baru diangkat digaji sebesar $¥ 900.000$ atau sekitar Rp 17 juta/bulan. Gaji guru di Jepang bisa tinggi karena Jepang menganggap bahwa guru adalah kunci dari sebuah pembangunan, maka dari itu mereka memberi penghargaan terhadap guru dengan gaji yang layak dan dapat membuat guru dan keluarganya sejahtera. Melihat Jepang begitu mengapresiasi guru, maka Indonesia juga perlu untuk meningkatkan gaji yang diberikan kepada guru. Jika melihat fakta yang ada pada sekarang ini, pemerintah Indonesia terkesan kurang peduli terhadap nasib para guru, tidak seperti pemerintah Jepang yang apresiasinya tinggi.

Hal ini dapat terlihat secara kasat mata oleh masyarakat, yaitu dari kondisi ekonomi para guru (khususnya guru honorer) yang kurang stabil. Saat ini, banyak orang yang memiliki minat rendah untuk menjadi guru dikarenakan gajinya dan tingkat kesejahteraan yang rendah. Apalagi anak milenial zaman sekarang yang mengedepankan gengsi mereka, sehingga makin berkurang saja orang yang minat menjadi guru di Indonesia. Meningkatkan kesejahteraan guru juga dapat menghapus persepsi masyarakat terhadap guru yang dipandang rendah, karena masyarakat sering membandingkan gaji guru dengan gaji seorang dokter atau seorang insinyur. Kesejahteraan seharusnya memperoleh prioritas perhatian untuk mempertinggi kinerja guru (Zulkifli, Darmawan, \& Sutrisno, 2014), karena gaji dapat mempengaruhi konsentrasi dan menjadi motivasi guru saat mengajar. Jika kenaikan gaji guru dan peningkatan kesejahteraan terjadi, maka minat orang-orang untuk menjadi guru akan tinggi. Jika minat masyarakat untuk menjadi guru tinggi, maka akan terjadi persaingan yang mana dapat meningkatkan kualitas guru karena calon guru akan menyiapkan dirinya semaksimal mungkin agar diterima menjadi guru.

\section{METODE PENELITIAN}

Penelitian ini merupakan studi pustaka, dan menggunakan pendekatan secara kualitatif, sehingga data-data yang diperoleh lebih mendalam yang dibantu dengan berbagai fakta di lapangan. Dalam penelitian ini juga terdapat beberapa data yaitu primer dan sekunder. Data primer diperoleh dari berbagai jurnal atau karya ilmiah yang sesuai dengan topik penelitian. Sementara itu, data sekunder diperoleh dari berbagai media, baik itu cetak maupun elektronik yang juga sesuai dengan pembahasan ini tentang kesejahteraan guru. karena itu, data-data 
yang sudah diperoleh selanjutnya dianalisis secara deduktif agar menghasilkan data yang akurat dan empiris.

\section{HASIL DAN PEMBAHASAN}

Berbicara tentang pendidikan tentu tak lepas dari peran guru sebagai perancang masa depan suatu bangsa, (Mansir, F., Purnomo, H., \& Tumin, T. 2020). Bangsa yang berkemajuan tidak lepas dari sistem pendidikan yang bermutu pula. Membangun sumber daya manusia yang berkualitas merupakan kunci yang sangat penting dalam suatu bangsa. Belajar dari jepang ketika bom atom dijatuhkan di hiroshima dan nagasaki pada tahun 1945 yang menyebabakan jepang menyerah pada perang duni ke 2 (1942-1945), kaisar Hirohito (bertahta 1926-1989) berupaya membangun kembali bangsanya yang sudah porak poranda itu. Ia memerintahkan menteri pendidikannya untuk menghitung berapa jumlah guru yang ada dan masih hidup. Salah satu sumber menyebutkan bahwa jumlah guru yang tersisa di jepang saat itu sebanyak 45.000 orang. Sejak saat itu, kaisar hirohito geriliya mendatangi para guru yang tinggal itu dan memberi perintah serta arahan, bahwa ada 5 perintah dan arahan yang haru dilaksanakan oleh para guru dan dipercaya dapat membangkitkan serta memajukan negara sakura ini kelak, antara lain:

1) Guru harus melaksanakan pendidikan yang bermutu

2) Guru harus disiplin dari murid

3) Guru harus lebih pintar dari murid

4) Pendidikan itu harus bisa menuntun industri

5) Saya akan kirimkan sebagian anda keluar negeri, pelajari dengan benar dan bawa pulang ke Jepang

Ini artinya, guru merupakan akar dari peradaban suatu bangsa, apabila akarnya kuat maka akan kuat pula seluruhnya, sebaliknya apabila akar dari sebuah pohon itu tidak kuat maka sudah dipastikan umur pohon itu tidak akan bertahan lama. Kualitas pendidikan sangat ditentukan dari kualitas gurunya, jadi guru itu merupakan orang-orang pilihan, menjadi guru tidak hanya bermodalkan cerdas saja tapi juga harus diiringi dengan kepribadian yang baik serta semangat yang tulus dari hati untuk mengajar. Guru adalah tempat kita belajar dan bertanya tentang apa yang belum kita pahami hal ini selaras dengan QS. An-Nahl: 43 yang artinya, "Dan kami tidak mengutus sebelum engkau (Muhammad) melainkan orang laki-laki yang kami beri wahyu kepada mereka; maka bertanyalah kepada orang yang mempunyai pengetahuan jika kamu tidak mengetahui”. 
Di indonesia sendiri para guru di tuntut untuk menjadi profesional dan memiliki karakter kuat positif, (Mansir, F 2018). Selain itu juga mempunya intlektual yang mumpuni, hal ini selaras ketika pemerintah membuat kebijakan bahwa seorang guru haruslah memiliki sertifikasi sebagai bukti bahwa dia sudah pantas dan telah memiliki syarat sah sebagai tenaga pendidik yang profesional dan siap memberikan pengajaran. Akan tetapi kebijakan yang diatur oleh pemerintah ini menurut penulis terlalu berat untuk diseleaikan oleh guru-guru baru, sedangkan di luar sana setiap hari, setiap pekan, setiap bulan, bahkan setiap tahun banyak guru yang harap cemas akan kesejahteraan dan kecukupan yang masih belum pasti.

Contoh kasus di lapangan yang ditemui adalah salah satu guru honorer yang berlokasi di sekolah Bengkulu yang mengeluhkan bahwa gaji yang dia dapat hanya 300.000 .00 padahal jam kerja dan tugas yang di lakukan tidak ada bedanya dengan guru-guru yang sudah PNS, ketika pulang mengajar guru-guru masih harus bekerja di sawah dan juga kebunnya untuk mencukupi kehidupan sehari-hari mereka yang tidak bisa mengandalkan gelar mulianya yaitu guru dalam memenuhi kebutuhan hidupnya, padahal kalau kita ingin membandingkan dengan negara tetangga misalnya Malaysia di sana guru mendapatkan gaji pokok maksimal sebesar Rm 6.982 atau setara 22,46 juta perbulan di Indonesia sendiri hanya 7 jutaan saja ini untuk guru yang sudah memiliki sertifikasi, melihat hal ini miris rasanya padahal guru adalah seorang yang berjuang dalam membangun masa depan bangsa namun kesejahteraan hidupnya masih patut dipertanyakan.

Guru disebut telah profesional apabila dia telah mampu menguasai kurikulum, materi pembelajaran, teknik, metode, kemampuan mengelolah kelas, komitmen, serta mampu menjadi suri tauladan siswanya dan juga masyarakat disekitarnya. Ada lima ukuran guru dinyatakan telah profesional yaitu:

a) Memiliki komitmen pada siswanya dalam mengajar

b) Secara mendalam menguasai bahan ajar dan cara mengajar

c) Bertanggung jawab memantau kemampuan belajar siswa melalui berbagai teknik evaluasi

d) Mampu berfikir sitematis dalam melakukan tugas

e) Menjadi bagian dari masyrakat belajar di lingkungan profesinya

Hal ini menunjukan betapa tingginya profesional guru, akan tetapi apabila kita melihat dari kemampuan, kesejahteraan dan fasilitas yang ada dan di dapatkan guru rasanya sangat sulit bagi guru untuk bertahan dan mau untuk terus melanjutkan profesinya, (Mansir, F. 2019). Melihat fenomena ini menurut penulis pemerintah harusnya lebih bijak lagi dalam 
membuat aturan dalam usaha menciptakan guru yang profesional dan mampu berkompetensi dalam dunia pendidikan. Hal yang harus dilakukan oleh pemerintah adalah melakukan prubahan dalam penyeleksian calon-calon guru dari awal seperti seleksi dalam memasuki fakultas pendidikan, seperti yang kita tahu passing grade untuk memasuki fakultas pendidikan di Indonesia masih sangat rendah bila dibanding dengan fakultas lainnya maka pemerintah harus menaikkannya kalau perlu harus sejajar dengan fakultas kedokteran karena yang menentukan maju atau tidaknya peradaban suatu bangsa adalah gurunya meskipun tidak terlepas dari hal lainnya. Pendidikan dan guru profesional adalah akar dari sebuah negara yang seharusnya mendapat perhatian lebih dari pemerintah, kebijakan pemerintah yang mengharuskan guru menjadi profesinal ketika guru sudah memasuki setengah jalan dalam menjadi seorang guru adalah keputusan yang kurang tepat, karena apabila pemerintah ingin serius dalam menciptakan guru yang berkualiatas maka harus bermula dari awal.

Setelah itu, pemerintah seharusnya memberikan pengontrolan terhadapat aturan yang telah dietapkan apakan sudah berjalan sesuai dengan apa yang direncanakan atau belum, contohnya undang-undang dasar 1945 pasal 31 ayat 1 dan 2 yang mengatakan tiap-tiap warga negara berhak mendapakan pengajaran (1) sedangkan ayat (2) menegaskan kepada pemerintah mengusahakan dan menyelenggarakan sistem pendidikan nasional, akan tetapi kalau kita lihat langsung dalam kehidupan sehari-hari masih sangat banyak anak kecil yang berjualan di tepi jalan, menjadi pemulung, dan juga pengemis. Ini sebuah potret dari fenomena bangsa Indonesia maka sudah selayaknya pemerintah melakukan kontrol kembali serta melakukan kejelasan dan ketegasan terhadap hukum yang di tegakkan.

Apabila di bandingkan dengan Amerika mereka melakukan program wajib belajar yang benar-benar mendapat perhatian dari pemerintahnya, jika ada seorang anak yang bekeliaran di jalanan pada saat jam sekolah maka pemerintah akan mencari siapa orang tuanya dan kenapa anaknya dibiarkan tidak sekolah, jika kemudian orang tua tidak memberikan alasan yang jelas maka orang tua tersebut bisa di penjarakan, seperti itulah ketegasan peraturan yang sudah seharusnya di contoh dan di terapkan oleh pemerintah di Indonesia, sehingga pendidikan itu merata tidak ada lagi anak kecil yang putus sekolah karena biaya dan hal lainnya.

Kemudian pemerintah juga harus memberikan pelatiahn-pelatihan kepada guru dalam rangka menciptakan guru yang profesional dan mampu berkompeten di dalam dunia pendidikan, sehingga guru benar-benar siap ketika harus memberikan pengajaran dan tauladan yang baik kepada peserta didik dan juga masyarakat di sekitarnya. Soal gaji juga sudah seharusnya pemerintah memberikan gaji yang sekiranya mampu mensejahterakan 
kehidupan para guru sehingga tidak ada lagi timpang sebelah, misalnya gaji guru di plosok desa sama dengan gaji guru di kota bahkan ada yang lebih kecil padahal mengajar di desa lebih sulit dari pada di kota, kalau di kota mengajar dianggap enak dan nyaman sebab semua fasilitas sudah lengkap dan juga didukung dengan kemampuan peserta didiknya yang sudah bagus, maka guru tidak terlalu sulit mengajar di kota.

Akan tetapi jika dibandingkan dengan mengajar di desa, sarana prasarananya sangat terbatas, bangunan sekolah yang sudah tua dan jarang mendapatkan perawatan yang sewaktuwaktu dapat membahayakan guru dan juga siswanya, serta akses jalan menuju ke sekolah yang sangat jelek mempersulit guru dan siswa untuk sampai ke sekolah. Kemampuan yang sebenarnya sangat membutuhkan pendidik yang berkualitas. Akan tetapi gaji yang kecil serta kurangnya perhatian dari pemerintah membuat enggan guru-guru yang profesional untuk mengajar di pelosok desa mereka lebih memilih mengajar di kota dengan segala fasilitasnya, dan pada akhirnya guru-guru barulah yang harus mengajar kesana dengan pengalaman yang kurang, akhirnya tidak mampu memberikan pengajaran yang baik di desa yang membuat ketimpanagn itu berjalan turun-temurun. Maka sudah seharusnya pemerintah melakukan sebuah perubahan dalam pendidikan di Indonesia mulai dari kualitas guru, kesetaraan, dan kesejahteraan sehingga kesalahan yang sudah terjadi turun-temurun ini dapat segera di selesaikan. Karena itu, sudah saatnya Indonesia menjadi negara yang berkualitas menjadi negara yang mampu mengelolah sumber daya manusianya menjadi guru-guru yang mempunyai semangat intelektual yang tinggi serta siap berkompentesi dengan negara-negara lain dalam membuat negara yang berkemajuan.

Kualitas tenaga pendidik atau guru di Indonesia saat ini masih rendah, peringkat pendidikan Indonesia pun masih rendah di dunia. Ada banyak faktor yang dapat mempengaruhi rendahnya kualitas kinerja guru di Indonesia. Seperti gaji yang rendah seperti yang sudah dijelaskan sebelumnya, yang berarti adanya perhatian yang sedikit terhadap guru di Indonesia oleh pemerintah. Kemudian banyak guru yang kurang update dengan teknologi. Sekarang adalah era Revolusi Industri 4.0, yang mana mengharuskan dunia pendidikan untuk ikut memutakhirkan sarana prasarana, metode dan strategi belajar agar sesuai dengan zaman. Keberadaan guru yang gagap teknologi ini, membuat para guru sulit untuk berpikir lebih maju karena teknologi saat ini dapat menunjang kinerja seorang guru.

Selain hal diatas, sekarang pemerintah tengah mengadakan pemerataan guru ke seluruh daerah di Indonesia. Namun hal ini nampaknya membuat masalah baru, yaitu ketidaksesuaian guru dalam mengajar. Misal di daerah terpencil hanya ada beberapa guru saja yang mengajar, sedangkan mata pelajaran wajib yang ada di Indonesia ada sekitar 12. Maka dari itu satu guru 
dapat merangkap menjadi pengampu mata pelajaran lain. Hal ini tentu saja menimbulkan masalah, karena guru yang tidak memiliki latar belakang kualifikasi suatu mata pelajaran maka tidak memiliki kelayakan untuk mengajar dikarenakan tidak menguasai materi yang harus diajarkan.

Tidak hanya karena program pemerataan guru saja, banyak sekali guru yang tidak memiliki tingkat kualifikasi sebagai pendidik yang sesuai di kota-kota besar. Banyak guru yang sudah memenuhi kualifikasi secara pendidikan, tetapi faktanya masih ada guru yang belum memenuhi kualifikasi secara kualitas diri. Masih banyak dari mereka yang belum bisa merealisasikan ekspektasi-ekspektasi dalam dunia pendidikan yang telah dipelajari selama masih menempuh pendidikan di perguruan tinggi, sehingga yang mereka pelajari hanya sebatas teori dan tidak diaplikasikan ketika menjadi guru.

Saat ini telah ada upaya dari pemerintah untuk meningkatkan kualitas kinerja sekaligus meningkatkan kesejahteraan guru yaitu adanya pelaksanaan sertifikasi terhadap kinerja guru. Sertifikasi guru ini diharapkan mampu meningkatkan mutu pendidikan di Indonesia melalui guru yang tersertifikasi. Namun mirisnya, fakta di lapangan menunjukkan bahwa sertifikasi pada guru tidak menunjukkan adanya peningkan kinerja guru, bahkan ada studi kasus di Jawa Barat yang mengungkapkan terjadinya penurunan kinerja guru jika dibandingkan dengan kinerja pada saat sebelum melaksanakan sertifikasi. Hasil penelitian banyak yang menunjukkan sertifikasi guru tidak berjalan lurus dengan kompetensi guru dalam mengajar (Rohman, 2016).

Nurcholis (2011) dalam (Zulkifli dkk., 2014) mengungkapkan hasil penelitiannya bahwa sertifikasi belum menunjukan perubahan yang berarti pada peningkatan kinerja guru. Dan berdasarkan hasil penelusuran atau studi awal di kabupaten Sumedang, dapat diidentifikasi bahwa guru-guru tersertifikasi memiliki masalah di antaranya pada aspek kompetensi profesional, seperti tidak mengembangkan model-model pembelajaran apalagi menerapkan sesuatu yang baru dalam proses pembelajaran di kelas, tidak melakukan penelitian dan menulis karya ilmiah, tidak melakukan refleksi diri terkait hasil pembelajaran, tidak mengembangkan kemampuan dalam teknologi pembelajaran atau IT, dan lain-lain, sehingga tidak ada bedanya antara kualitas sebelum disertifikasi dengan kualitas setelah disertifikasi (Fahdini, Mulyadi, Suhandani, \& Julia, 2014).

Selain masalah-masalah tersebut, berdasarkan penelitian yang dilakukan oleh Kardiyem di Kabupaten Grobogan menunjukkan bahwa masih ada guru tersertifikasi yang kurang mampu untuk menerapkan SK dan KD, pengembangan materi, dan memahami pola pemikiran peserta didik. Masalah lain juga diungkapkan oleh penelitian yang dilakukan oleh 
Badrun terhadap $10 \%$ guru tersertifikasi di Kabupaten Sleman, penelitian tersebut menunjukkan bahwa masih ada guru tersertifikasi yang belum menguasai atau belum bisa untuk membuat/menyusun RPP. Motivasi kebanyakan guru untuk mengikuti program sertifikasi adalah aspek finansial, yaitu ingin segera mendapatkan tunjangan. Jadi, ketika seorang guru sudah lolos sertifikasi dan mencapai apa yang diinginkan (tunjangan), maka usaha peningkatan kualitas mengajarnya akan menurun.

Oleh karena itu baik dari pemerintah, masyarakat, maupun para guru hendaknya melakukan pengawasan yang lebih lagi terhadap jalannya proses sertifikasi sehingga benarbenar dapat terlaksana sesuai dengan tujuan yang diinginkan. Bahkan jika perlu dibentuk badan pengawas untuk memantau jalannya proses sertifikasi guru ini, agar terhindar dari kecurangan-kecurangan yang dapat merusak image guru maupun pemerintah. Selain itu juga dapat menghindari dari pendidikan yang tidak berkualitas dan tidak profesional dan praktikpraktik pendidikan yang menyimpang lainnya. Meskipun demikian, dalam pelaksanaan pencairan dan tunjangan sertifikasi, masih terjadi hambatan pada administrasi di tingkat daerah. Jadi, guru yang telah tersertifikasi juga tidak langsung mengalami peningkatan kesejahteraan secara finansial.

Selain program sertifikasi untuk meningkatkan kualitas kinerja guru, pemerintah juga telah mengadakan program pelatihan kepada guru. Program ini menggunakan dana dari pemerintah yaitu Continuous Professional Development (CPD). Namun, fakta yang ada menunjukkan bahwa program ini tidak sepenuhnya berhasil, karena tidak banyak guru yang mau diberikan pelatihan. Kalaupun mengikuti, itu merupakan bentuk formalitas untuk menunjukkan bahwa guru telah mengikuti program yang dijalankan oleh pemerintah. Tak jarang juga keikutsertaan guru karena bentuk keterpaksaan karena adanya perintah dari pihak sekolah maupun keputusan dari kepala sekolah. Jika pelatihan yang diadakan dan dilakukan secara terpaksa atau mau tak mau oleh guru, maka sehebat atau sebagus apapun pelatihan yang diadakan, guru akan susah untuk mengambil manfaat atau pelajaran dari pelatihan tersebut.

Berdasarkan hal diatas, nampaknya Indonesia perlu meningkatkan pengawasan terhadap sertifikasi guru demi menjaga dan meningkatkan kualitas guru. Seperti melakukan penelusuran terlebih dahulu terhadap guru yang akan lolos sertifikasi, karena guru seharusya dapat menjadi jalan untuk kecerahan masa depan pendidikan di Indonesia melalui keprofesionalan yang dimiliki. Mengingat banyak hasil dari penelitian mengungkapkan tingkat keprofesionalan guru tersertifikasi masih jauh dari kualifikasi profesional yang 
sesungguhnya, pemerintah selayaknya mengadakan upaya-upaya serius dan mengadakan pembaruan terhadap program peningkatan kualitas guru.

Solusi yang dapat dilakukan untuk menangani rendahnya kualitas kinerja guru di Indonesia dapat diawali oleh guru itu sendiri. Hendaknya guru meningkatkan kesadaran diri bahwa dengan menjadi guru, kontribusinya sangat besar bagi pembangunan bangsa. Apa yang dilakukan oleh guru ini akan membentuk masa depan dari bangsa di masa depan. Maka dari itu, kesadaran untuk meningkatkan kemampuan serta keprofesionalan dalam peran dan tugasnya dalam dunia pendidikan sangat penting dilakukan oleh para tenaga pendidik. Jika guru melakukan pengembangan diri sebagai bentuk kesadaran untuk menghasilkan sumber daya manusia yang luar biasa di masa depan, maka akan terjadi peningkatan kualitas pendidikan untuk kepentingan pembangunan nasional agar tercapainya tujuan pendidikan nasional.

Setelah kesadaran pada diri seorang guru untuk meningkatkan kualitas diri terbentuk, maka dilakukan perencanaan yang mendasar pada kegiatan pendidikan yang dapat dimulai dari lingkungan yang paling kecil terlebih dahulu, yaitu lingkungan sekolah. Guru perlu melakukan perencanaan terhadap apa yang harus dilakukan dalam kegiatan pembelajaran di sekolah untuk mencapai tujuan yang harus dicapai dalam pendidikan di tingkat sekolah yang sudah ditetapkan. Perencanaan perlu diterapkan pada seluruh aspek kegiatan pembelajaran yang akan dilakukan oleh seorang guru. Perencanaan merupakan kegiatan yang menetapkan apapun yang harus dilakukan oleh seorang guru, termasuk metode belajar, strategi belajar, skenario pembelajaran, bahkan sampai ke pengelolaan dana pendidikan.

Hal yang tak kalah penting yang harus dilakukan oleh seorang guru adalah evaluasi. Evaluasi dapat menjadi sebuah tahapan yang dapat meningkatkan kualitas kinerja seorang guru agar dapat mengetaui sejauh mana diri seorang guru itu telah menguasai materi pembelajaran atau menguasai kegiatan pembelajaran dalam melaksanakan tugas dan kewajibannya sebagai seorang pendidik. Evaluasi tentunya tidak hanya dilakukan oleh guru saja, tetapi dilakukan juga oleh seluruh sekolah, dinas pendidikan bahkan sampai Kementrian Pendidikan. Walaupun evaluasi merupakan kegiatan rutin yang telah berjalan sejak dulu, hal ini perlu ditingkatkan lagi apalagi dalam hal keseriusan untuk menanggapi hasil evaluasi saja. Harus ada aksi yang benar-benar dijalankan sebagai bentuk dari tanggapan evaluasi, bukan hanya evaluasi saja dan kembudian berhenti pada hasil dari evaluasi tersebut.

Dalam solusi peningkatan kualitas kinerja dan kesejahteraan guru, pemerintah seharusnya memberikan perhatian dan effort yang lebih serius lagi. Karena dalam pembangunan negara, guru adalah kuncinya. Peran guru sangatlah krusial, ada korelasi antara 
kualitas kinerja guru dengan kemajuan suatu bangsa. Kunci dari kemajuan negara adalah pembangunan, dan kunci dari pembangunan negara adalah pendidikan, kunci pendidikan adalah guru. Tanpa adanya guru yang berkualitas dan profesional, tidak akan ada murid yang bagus. Dengan tidak adanya murid yang bagus aka tidak akan ada Sumber Daya Manusia yang bagus, yang dapat berkontribusi untuk membuat negara menjadi lebih maju lagi. Maka dari itu diharapkan pemerintah dapat mengupayakan pembangunan pendidikan yang lebih lagi, khususnya pada peningkatan kesejahteraan dan kualitas kinerja guru di Indonesia.

\section{KESIMPULAN}

Seorang guru profesional membutuhkan pengakuan dari berbagai pihak, tidak hanya pengakuan secara sosial di masyarakat. Akan tetapi, pengakuan dari pemerintah. Dengan pengakuan tersebut, maka guru profesional akan banyak memberikan kontribusi pada sektor pendidikan dalam hal ini pengajaran. Sehingga, persoalan kesejahteraan bukan lagi hal yang tabuh untuk diperbincangkan namun menjadi kewajiban untuk diberikan pada guru era digital. kesejahtereaan bagi guru menjadi penting dan utama dalam mewujudkan pendidikan nasional karena segala yang berkaitan dengan pendidikan maka kuncinya ada pada SDM yaitu guru.

\section{DAFTAR PUSTAKA}

Diyanti, Santoso, S., Octoria, D. (2016). "Pengaruh Prestasi Belajar dan Presepsi Mahasiswa tentang Kesejahteraan Guru Terhadap Minat menjadi Guru Pada Mahasiswa Prodi Pendidikan Akuntansi FKIP UNS. Jurnal Tata Arta Uns, Vol 2. No 2.

Fahdini, R., Mulyadi, E., Suhandani, D., \& Julia. (2014). Identifikasi Kompetensi Guru Sebagai Cerminan Profesionalisme Tenaga Pendidik di Kabupaten Sumedang. Mimbar Sekolah Dasar, 1, 34.

Mansir, F., Purnomo, H., \& Tumin, T. (2020) PENERAPAN PEMBELAJARAN PENDIDIKAN AGAMA ISLAM BERBASIS SAINS BUDAYA LOKAL DI SEKOLAH DAN MADRASAH. TARBAWY: Indonesian Journal of Islamic Education, 7(1), 70-79.

Mansir, F. (2019). IMPLICATIONS OF TEACHER CERTIFICATION ON PROFESSIONALISM AND WELFARE OF 21TH CENTURY PAI TEACHERS. Tadrib, 5(2), 138-152.

Mansir, F. (2018). DISKURSUS PENDIDIKAN KARAKTER DI PEGURUAN TINGGI KEAGAMAAN ISLAM PADA ERA MILENIAL. Tadrib, 4(2), 280-300. 
Rohman, M. (2016). Problematika Guru dan Dosen dala Sistem Pendidikan Nasional. Jurnal Kependidikan dan Kemasyarakatan, 14.

Sanaky, H. (2005). “Sertifikasi dan Profesionalisme Guru di Era Reformasi”. Jurnal Pendidikan Islam.

Simatupang, R. (2018). "Korelasi Kesejahteraan Guru Dengan Motivasi Kerja Dalam Pelaksanaan Prosespembelajran di SMA Negeri 1 Pollung Tahun Pembelajaran 2017/2018”. Jurnal Christian humaniora, Vol 2. No 2. 2018

Sulhan, Najib. (2016). “Guru yang Berhati Guru”. Jakarta. Penerbit Zikrul Hakim.

Zulkifli, M., Darmawan, A., \& Sutrisno, E. (2014). Motivasi Kerja, Sertifikasi, Kesejahteraan dan Kinerja Guru. Jurnal Psikologi Indonesia, 3, 149. 